\title{
Birch pollen season in southern Poland in 2017
}

\author{
Małgorzata Malkiewicz', Agnieszka Lipiec², Katarzyna Dąbrowska-Zapart' ${ }^{3}$, Kazimiera Chłopek3, \\ Monika Ziemianin ${ }^{4}$, Krystyna Piotrowska-Weryszko ${ }^{5}$, Elżbieta Weryszko-Chmielewska ${ }^{6}$, Adam Rapiejko ${ }^{7,8}$, \\ Dariusz Jurkiewicz ${ }^{9}$, Piotr Rapiejko ${ }^{9}$ \\ ${ }^{1}$ Laboratory of Paleobotany, Department of Stratigraphical Geology, Institute of Geological Sciences, \\ University of Wroclaw, Poland \\ ${ }^{2}$ Department of Prevention of Environmental Hazards and Allergology, Medical University of Warsaw, Poland \\ ${ }^{3}$ Faculty of Earth Sciences, University of Silesia, Sosnowiec, Poland \\ ${ }^{4}$ Department of Clinical and Environmental Allergology, Jagiellonian University Medical College, Cracow, Poland \\ ${ }^{5}$ Department of General Ecology, University of Life Sciences, Lublin, Poland \\ ${ }^{6}$ Department of Botany, University of Life Sciences, Lublin, Poland \\ ${ }^{7}$ Oxford Archaeology Ltd., Oxford, England \\ ${ }^{8}$ Allergen Research Center Ltd., Warsaw, Poland \\ ${ }^{9}$ Department of Otolaryngology with Division of Cranio-Maxillo-Facial Surgery in Military Institute of Medicine, \\ Warsaw, Poland
}

Abstract: This paper presents the course of the pollen season of birch in Zielona Gora, Wroclaw, Opole, Sosnowiec, Piotrkow Trybunalski, Warsaw, Cracow and Lublin in 2017. Measurements were performed by the volumetric method (Burkard and Lanzoni pollen samplers). Pollen season was defined as the period in which $98 \%$ of the annual total catch occurred. Pollen season of birch in 2017 started more than $4-5$ days earlier in comparison to 2016. The earliest onset of the birch pollen season was recorded in Zielona Gora, Wroclaw, Opole and Warsaw $-31^{\text {st }}$ March. The highest daily pollen count was recorded in Wroclaw $-2028 \mathrm{P} / \mathrm{m}^{3}$ (15t April).

Key words: aeroallergens, pollen count, birch (Betula), 2017

D irch pollen, next to alder and hazel pollen, is

D a very common cause of pollinosis in Central and Northern Europe [1,2]. Birch is wind-pollinated and produce large amounts of light pollen. The production of the pollen from a single flower may amount above 20 thousand grains. Small and light pollen grains enable their wide dispersal. An average border of dispersion of birch pollen amounts almost $120 \mathrm{~km}[3]$.

The birch pollen season is a compact and dynamic one. In many cities of Poland it starts with the beginning of April, although the maximum concentration appears in second half of this month [4].
The threshold concentration of birch pollen causing the first allergy symptoms has been established for Poland at $20 \mathrm{P} / \mathrm{m}^{3}[5,6]$. At a concentration of $75 \mathrm{P} /$ $\mathrm{m}^{3}$ all individuals allergic to birch pollen suffer from pollinosis, and at a concentration exceeding $155 \mathrm{P} / \mathrm{m}^{3}$, symptoms of dyspnoea can be observed in allergic patients.

Aim

The aim of the study was to compare the birch pollen concentration in the air of selected cities in southern Poland: Zielona Gora, Wroclaw, Opole, So- 
snowiec, Piotrkow Trybunalski, Warsaw, Cracow and Lublin in 2017.

\section{Material and method}

In 2017, the measurements of the pollen concentration in the study sites were performed with the volumetric method using Burkard and Lanzoni pollen samplers. Microscopic observations were performed on preparations obtained in a 7-day cycle with assessment of 24-hour periods. The length of the birch pollen seasons was determined with the $98 \%$ method. Pollen concentrations were expressed as the number of pollen grains in $1 \mathrm{~m}^{3}$ of air per day $\left(\mathrm{P} / \mathrm{m}^{3}\right)$. The course of the pollen seasons in each city is shown in the graphs (fig. 1-8).

\section{Results and discussion}

In 2017 , the pollen season of birch determined using the $98 \%$ method, started in the second half of March and at the beginning of April (tab. 1).

The dates of the beginning of birch pollen season in the analysed cities in Southern Poland were very similar. The earliest onset of the birch pollen season was recorded in Zielona Gora, Wroclaw, Opole and Warsaw - 31 $1^{\text {st }}$ March (tab. 1). The latest the birch pollen season has began was on $2^{\text {nd }}$ April (Lublin). The comparison of the beginning of the birch pollen season in 2017 indicates that the season began 4-5 days earlier than in the 2016 [7].

In majority of the analysed cities the highest birch pollen concentrations were detected in the first decade of April ( $1^{\text {st }}-5^{\text {th }}$ April) and on $10^{\text {th }}$ April in Warsaw and Piotrkow Trybunalski. The highest daily pollen count was recorded in Wroclaw $-2028 \mathrm{P} / \mathrm{m}^{3}$. In other cities the maximum concentrations ranged from $1070 \mathrm{P} / \mathrm{m}^{3}$ in Sosnowiec to $1854 \mathrm{P} / \mathrm{m}^{3}$ in Piotrkow Trybunalski (fig. 2, 4, 5), although in Cracow, only $697 \mathrm{P} /$ $\mathrm{m}^{3}$ (fig. 7). Comparing to 2016 the maximum concentrations of birch pollen in 2017 were very low. In Wroclaw, Opole and Zielona Gora this parameter was 1,5-2 times lower, in Sosnowiec and Lublin were 3-4 times lower and in Cracow up to 6 times lower [7]. It is worth noting that in 6 cities (Wroclaw, Zielona Gora, Opole, Sosnowiec, Cracow and Lublin) the maximum birch pollen concentration was recorded on days $1-4$ after the beginning of season (fig. 1-4, 7, 8) and in Warsaw and Piotrkow Trybunalski on days 9-10 (fig. 5, 6).

The highest annual pollen sum of birch pollen grains (SPI) were recorded in Zielona Gora - 11303 and Wroclaw - 10 338. They were similarly high in Piotrkow Trybunalski and Opole (above 9300). In other cities SPI ranged between 3858 in Sosnowiec to 8899 in Warsaw (tab. 1). In 2017, the total annual pollen sum was nearly 2-5-fold lower than in 2016 [7].

The number of days with a concentration equal or higher than $20 \mathrm{P} / \mathrm{m}^{3}$ was 32 in Lublin, 25-28 in

Table 1. Characteristics of birch pollen season in 2017.

\begin{tabular}{|c|c|c|c|c|c|}
\hline Site & $\begin{array}{l}\text { Pollen season period by } \\
\text { the } 98 \% \text { method }\end{array}$ & $\begin{array}{l}\text { Maximum pollen count } \\
\left(\mathrm{P} / \mathrm{m}^{3}\right) \text { and date }\end{array}$ & $\begin{array}{l}\text { Annual pollen } \\
\text { sum }\end{array}$ & $\begin{array}{l}\text { Days number above } \\
\text { threshold } 20 \mathrm{P} / \mathrm{m}^{3}\end{array}$ & $\begin{array}{l}\text { Days number above } \\
\text { threshold } 75 \mathrm{P} / \mathrm{m}^{3}\end{array}$ \\
\hline Zielona Gora & $31.03-2.05$ & $\begin{array}{l}1785 \\
1.04\end{array}$ & 11303 & 28 & 19 \\
\hline Wroclaw & $31.03-9.05$ & $\begin{array}{l}2028 \\
1.04\end{array}$ & 10338 & 23 & 16 \\
\hline Opole & $31.03-8.05$ & $\begin{array}{l}1786 \\
2.04\end{array}$ & 9377 & 26 & 17 \\
\hline Sosnowiec & $1.04-15.05$ & $\begin{array}{l}1070 \\
5.04\end{array}$ & 3858 & 23 & 12 \\
\hline $\begin{array}{l}\text { Piotrkow } \\
\text { Trybunalski }\end{array}$ & $1.04-8.05$ & $\begin{array}{l}1854 \\
10.04\end{array}$ & 9549 & 26 & 20 \\
\hline Warsaw & $31.03-26.04$ & $\begin{array}{r}1563 \\
10.04\end{array}$ & 8899 & 25 & 17 \\
\hline Cracow & $1.04-9.05$ & $\begin{array}{l}697 \\
5.04\end{array}$ & 4845 & 21 & 12 \\
\hline Lublin & $2.04-22.05$ & $\begin{array}{l}1552 \\
5.04\end{array}$ & 8762 & 32 & 16 \\
\hline
\end{tabular}




\section{MEDIGAL AEROBIOLOGY}

ORIGINAL PAPER

Figure 1. Birch pollen count in Zielona Gora in 2017.

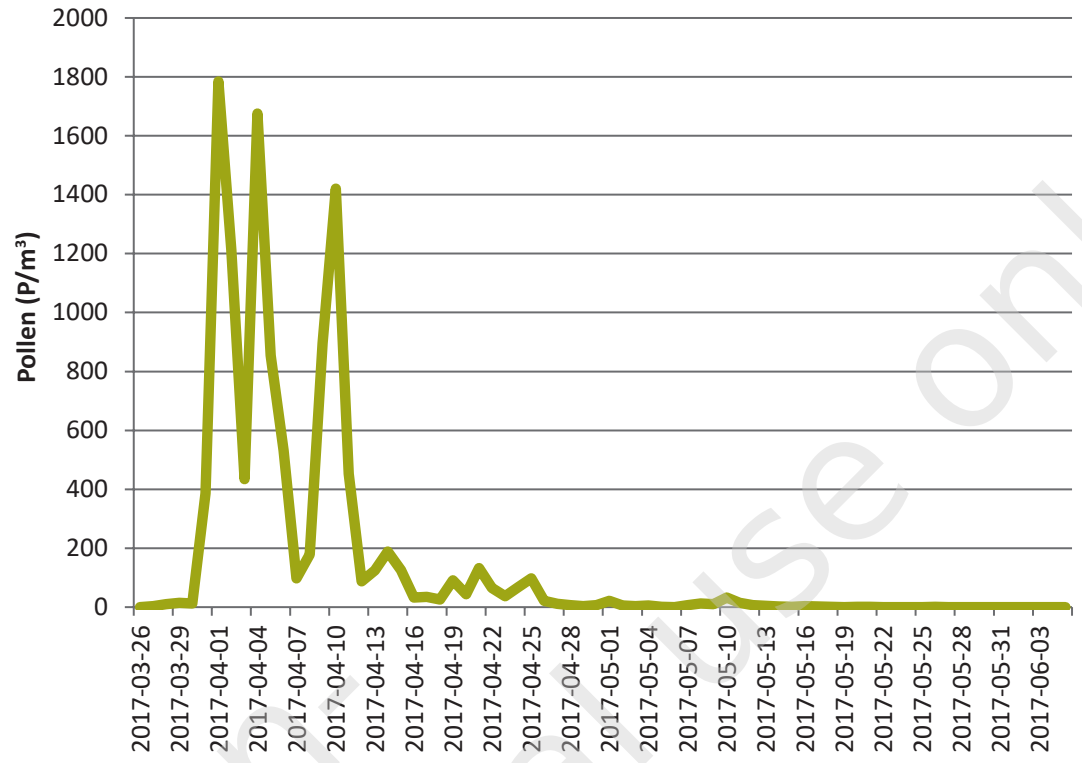

Figure 2. Birch pollen count in Wroclaw in 2017.

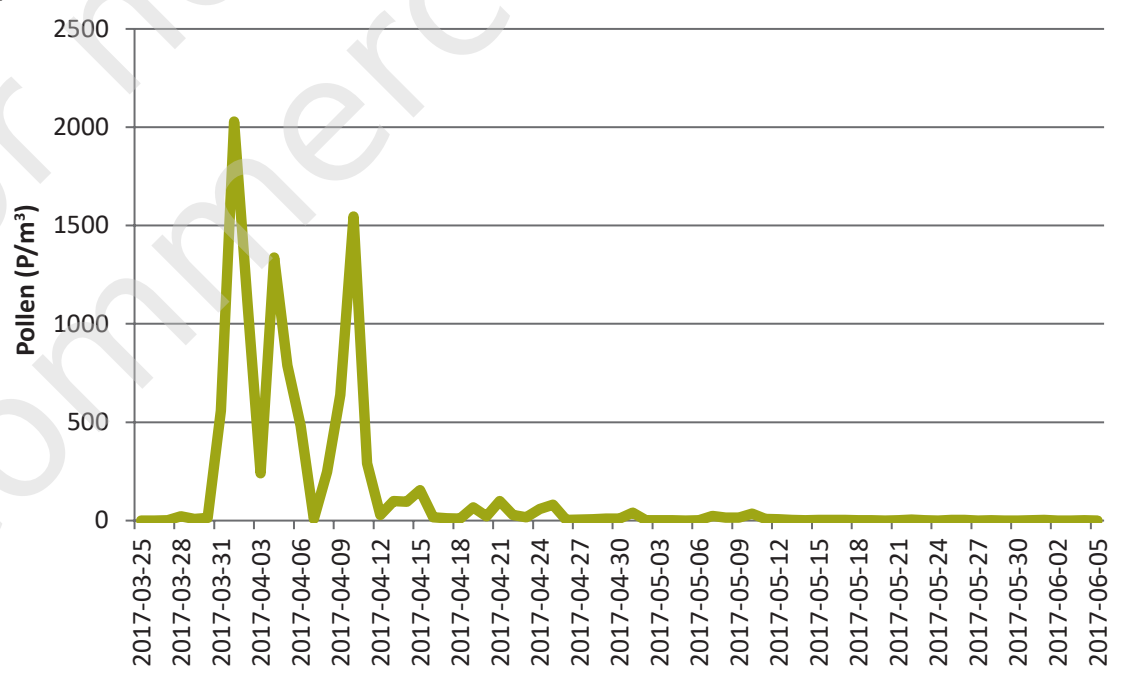

Figure 3. Birch pollen count in Opole in 2017.

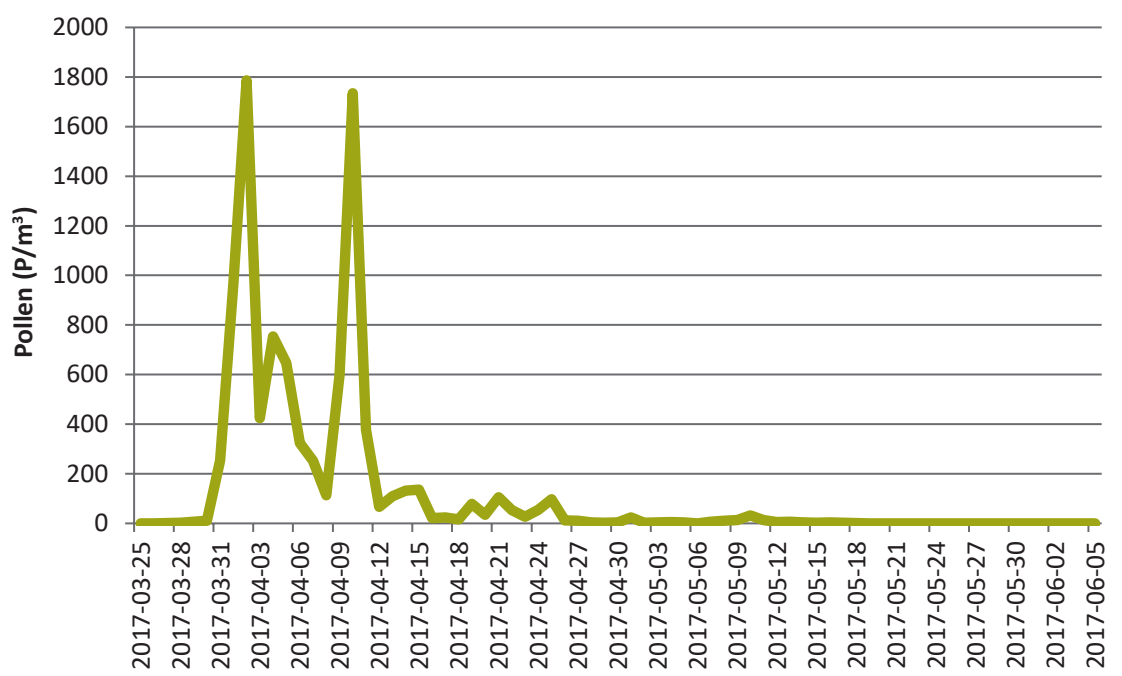


Figure 4. Birch pollen count in Sosnowiec in 2017.

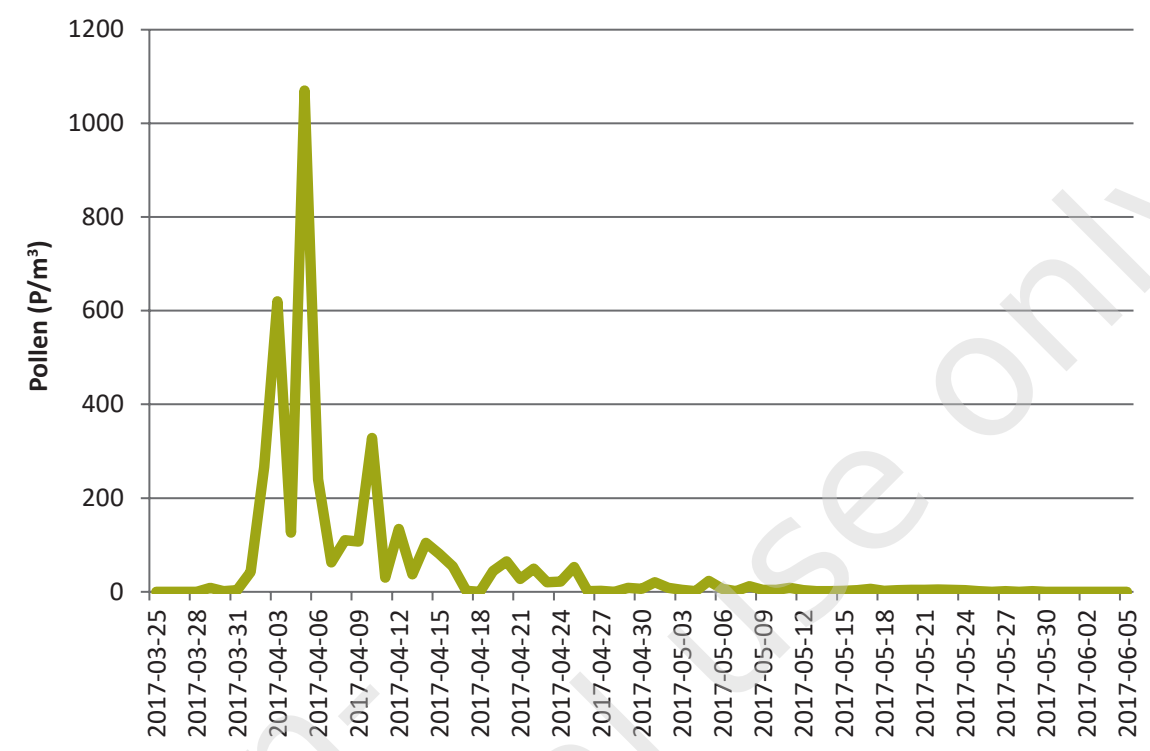

Figure 5. Birch pollen count in Piotrkow Trybunalski in 2017.

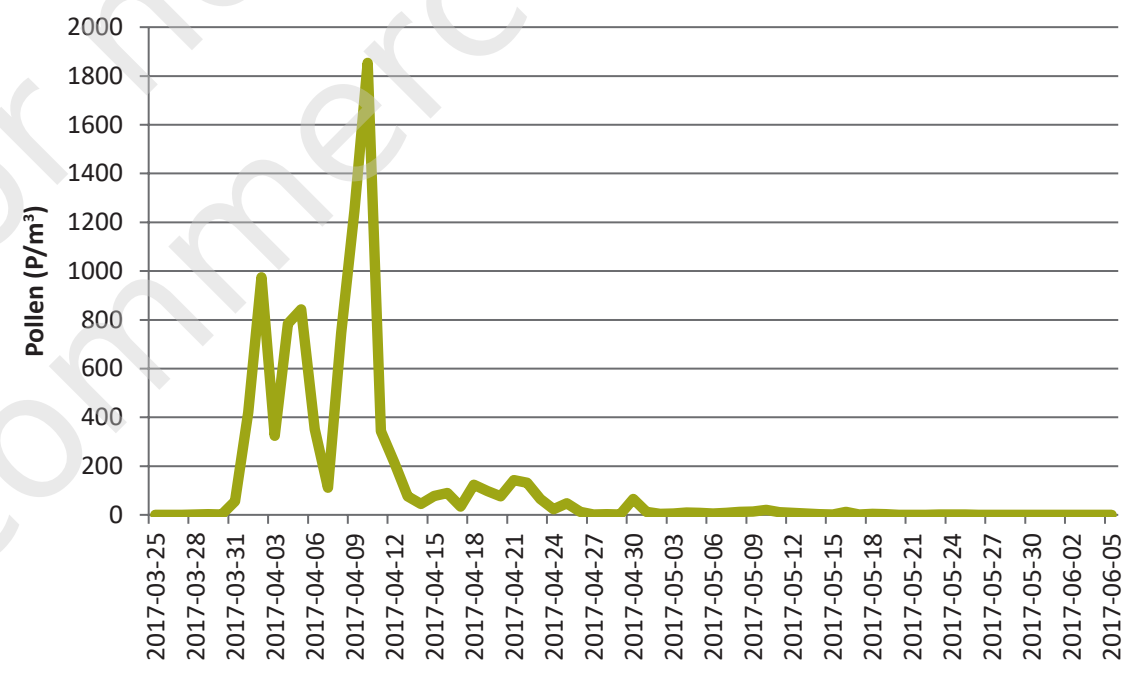

Figure 6. Birch pollen count in Warsaw in 2017.

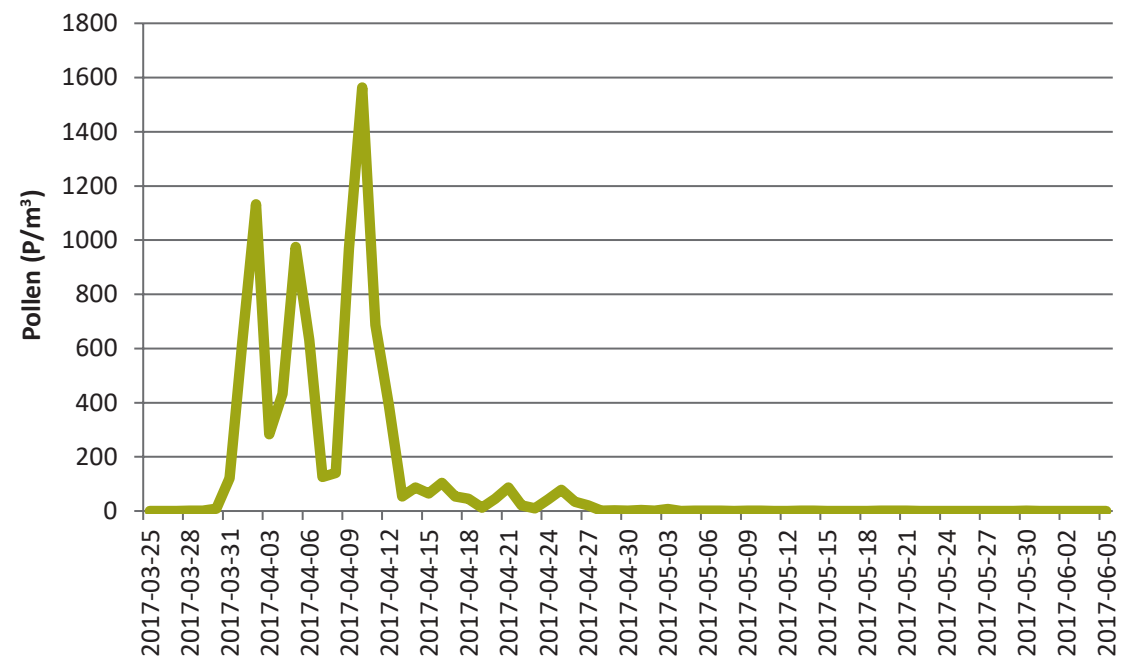


Figure 7. Birch pollen count in Cracow in 2017.

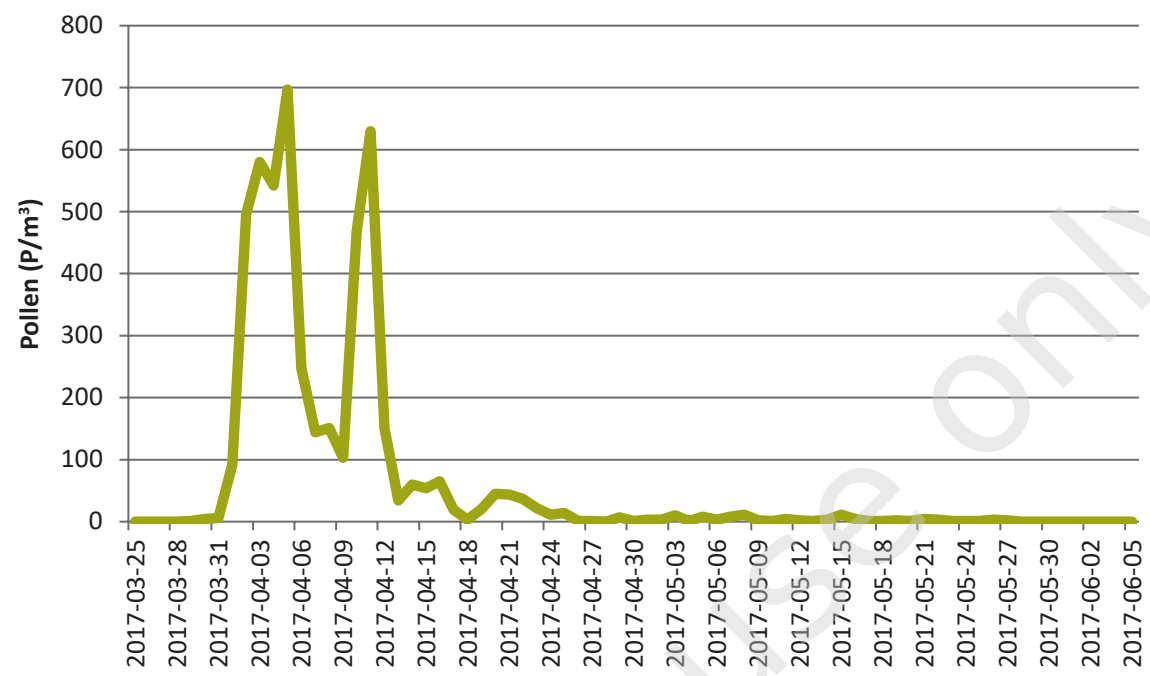

Figure 8. Birch pollen count in Lublin in 2017.

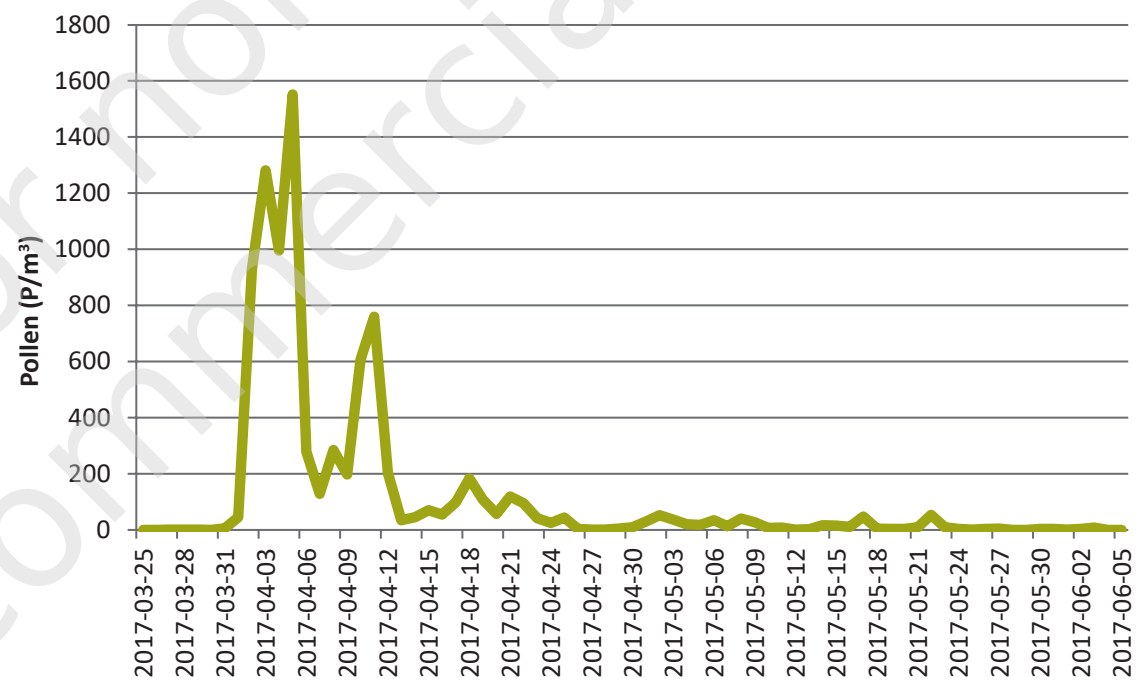

Warsaw, Piotrkow Trybunalski, Opole and Zielona Gora, 21-23 in Cracow, Sosnowiec and Wroclaw. In the analysed cities the threshold value of $75 \mathrm{P} / \mathrm{m}^{3}$ (concentration causing severe clinical symptoms) $[5,6]$ was exceeded for 12-20 days.

\section{Conclusions}

In 2017, the birch pollen season in the cities in Southern Poland started about 4-5 days earlier compared to 2016. The earliest onset of the birch pollen season was recorded in Zielona Gora, Wroclaw, Opole and Warsaw $-31^{\text {st }}$ March.

The end of the birch pollen season was noted in the first and second part of May (2-22.05).

The maximum concentrations of birch pollen in majority of the cities were noted in the beginning of
April (1-5.04). The highest daily pollen count was recorded in Wroclaw - $2028 \mathrm{P} / \mathrm{m}^{3}$.

In most cities birch pollen season was long and lasted an average of 39 days.

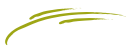

\section{References:}

1. Wihl JA, Ipsen B, Nuchel PB et al. Immunotherapy with partially purified and standardized tree pollen extracts. Allergy 1998, 43: 363-369.

2. Emberlin J, Detandt M, Gehrig R et al. Responses in the start of Betula (birch) pollen seasons to recent changes in spring temperatures across Europe. Int J Biometeorol 2002, 46: 159-170.

3. Rapiejko P. Alergeny pytku roślin. Medical Education, Warszawa 2008 
4. Weryszko-Chmielewska E (ed.). Pytek roślin $w$ aeroplanktonie różnych regionów Polski. Wyd. Katedra i Zakład Farmakognozji Wydziału Farmaceutycznego AM, Lublin 2006.

5. Rapiejko P, Lipiec A, Wojdas A, Jurkiewicz D. Threshold pollen concentration necessary to evoke allergic symptoms. Int Rev Allergol Clin 2004, 10(3): 91-94.

6. Rapiejko P, Stankiewicz W, Szczygielski K, Jurkiewicz D. Progowe stężenia pytku roślin niezbędne do wywołania objawów alergicznych. Otolaryngol 2007, 61(4): 591-594.

7. Weryszko-Chmielewska E, Piotrowska-Weryszko K, Haratym $W$ et al. Betula pollen season in southern Poland in 2016. Alergoprofil 2016, 12(2): 99-100.

Authors` contributions:

Malkiewicz M: 55\%; Lipiec A: 5\%; Dąbrowska-Zapart K: 5\%; Chłopek K: 5\%; Ziemianin M: 5\%; Piotrowska-Weryszko K: 5\%; Weryszko-Chmielewska E: 5\%; Rapiejko A: 5\%; Jurkiewicz D: $5 \%$; Rapiejko P: $5 \%$
Conflict of interests:

The authors declare that they have no competing interests.

Financial support:

Research in Opole, Zielona Gora and Piotrkow Trybunalski funded by Allergen Research Center Ltd. (Ośrodek Badania Alergenów Środowiskowych Sp. z 0.0.).

Ethics:

The contents presented in this paper are compatible with the rules the Declaration of Helsinki, EU directives and standardized requirements for medical journals.

\section{Corresponding author:}

\section{Malgorzata Malkiewicz}

Laboratory of Paleobotany,

Department of Stratigraphical Geology, Institute of Geological Sciences,

University of Wroclaw

50-205 Wrocław, ul. Cybulskiego 30

e-mail: malgorzata.malkiewicz@uwr.edu.pl 